\title{
25 Research Soure \\ Selection of Contrasting Parents for Drought Tolerance in Sunflower (Helianthus Annuus L.)
}

Nancy Gabriela Grandón ( $\sim$ grandon.nancy@inta.gob.ar)

Instituto Nacional de Tecnología Agropecuaria: Instituto Nacional de Tecnologia Agropecuaria https://orcid.org/0000-0002-8825-1714

\section{Eugenia Alejandra Martin}

Universidad Nacional de Rosario Facultad de Ciencias Agrarias

\section{Emanuel Mauro Cicconi}

INTA: Instituto Nacional de Tecnologia Agropecuaria

Carolina del Pilar Díaz

INTA: Instituto Nacional de Tecnologia Agropecuaria

Eva María Celia Mamaní

INTA: Instituto Nacional de Tecnologia Agropecuaria

María Valeria Moreno

INTA: Instituto Nacional de Tecnologia Agropecuaria

\section{Research Article}

Keywords: Sunflower Inbred Lines, SSR markers, Drought Tolerance, Phenotyping, Water Use Efficiency, Vapor 27 Pressure Deficit Response.

Posted Date: December 20th, 2021

DOI: https://doi.org/10.21203/rs.3.rs-1135239/v1

License: (1) (i) This work is licensed under a Creative Commons Attribution 4.0 International License.

Read Full License 
Selection of contrasting parents for drought tolerance in sunflower (Helianthus annuus $\mathbf{L}$.)

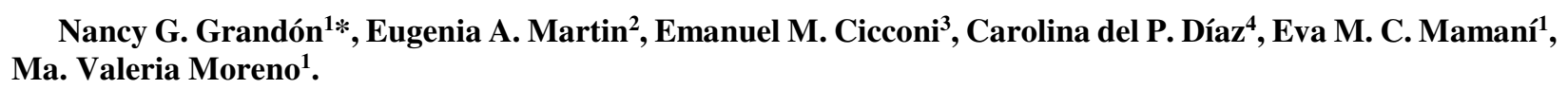
Ma. Valeria Moreno ${ }^{1}$.

${ }^{1}$ Laboratorio de Biotecnología, INTA-EEA Manfredi. Ruta Nac. № 9. Km 636. (5988) Manfredi, Córdoba, Argentina.

${ }^{2}$ IICAR-CONICET. Campo Experimental Villarino, CC No 14 (S2125ZAA). Zavalla, Santa Fe, Argentina.

${ }^{3}$ Asesor técnico. Buenos Aires 563. (5986) Oncativo, Córdoba, Argentina.

${ }^{4}$ Asesora estadística. Santa Rosa 320. Oficina A, $5^{\circ}$ piso (X5000ESH). Sucursal Córdoba, Argentina.

*Corresponding author: grandon.nancy@inta.gob.ar

Abstract The aim of this research was select the best combination of contrasting parents to develop a mapping population for drought tolerance, based on phenotypic and genotypic data. Phenotyping was conducted in a greenhouse during 16 days at vegetative stage under well-watered (WW) and water-deficit (WD) conditions. Traits evaluated were: gain of leaf area (GLA), total water use (TWU), net assimilation rate (NAR), water use efficiency (WUE) and transpiration rate (TR) response to vapor pressure deficit (VPD) (slope and breakpoint). Genotyping was performed with 127 SSR markers and a cluster analyses was conducted. An important interaction was observed for NAR, WUE and breakpoint in the VPD response. Under WD conditions, all genotypes showed lower GLA and TWU, whereas NAR and WUE increased its values. All genotypes showed reduction of the slope and breakpoint in high VPD response on WD. PCA analysis explains the $80 \%$ of the total variability. PC1 discriminated HA89 and R419 due to a lower slope and higher breakpoint, while PC2 separated by water treatment based on the WUE and TWU values. Nighty nine SSR marker were amplified detecting 262 alleles. Cluster analyzes showed two main groups, one including HAR4 and B59 and the other one including five remaining genotypes. According to these results, only R419xHA64 and HA89xHAR4 had a greater genetic distance (1.08), besides a high polymorphism level between ILs (about 60\%). Therefore, we conclude that these would be the best combination of contrasting parents to develop mapping populations for drought tolerance in sunflower.

Keywords Sunflower Inbred Lines, SSR markers, Drought Tolerance, Phenotyping, Water Use Efficiency, Vapor Pressure Deficit Response. 


\section{Introduction}

Sunflower (Helianthus annuus var. macrocarpus (DC) Cockerell) is the fourth most important sources of vegetable oil in the world and the second most important in Argentina. In this sense, the country is the fourth producer with $6.2 \%$ of world oil production for the 2021/2022 season (USDA 2021). In this season, a harvested world area of 27 million hectares was recorded, with a seed production of 54.92 million tons; being Ukraine, Russia, European Union and Argentina the main producers for the 2021/2022 season (USDA 2021).

The cultivated sunflower is an annual plant and belongs to the family Asteraceae. It is a diploid species $(2 n=2 x=34)$ with a haploid genome size of $3.6 \mathrm{~Gb}$ (Badouin et al. 2017). Is originally from the center-east region of the United States and from there it spread to the rest of the world. In Argentina, it was introduced in the 19th century by Jewish immigrants, which brought with them seeds of sunflower Russian varieties. Then, between 1930 and 1959 it expanded as an oilseed crop. From 1960, INTA through the genetic breeding, developed the first local varieties. This created a rich genetic variability that allowed the conformation of Argentinian germplasm from materials of Russian origin, local varieties and wild species (Vásquez 2002).

Actually, the sunflower breeding program of Instituto Nacional de Tecnología Agropecuaria (INTA) has released germplasm of phytotechnical value, not only in Argentina but also in the United States and Europe; thus contributing to increase the genetic gain of this species. Although the main objective is to increase the oil yield, they also conduct their efforts to obtain lines with a good behavior against Verticillium, Downy mildew and Sclerotinia, as well as industrial quality (high oleic acid) and drought tolerance (González et al. 2015; González 2016). In this context, the Active Germplasm Bank of the Manfredi Experimental Station (AGB-IM) of INTA hosts about 1200 accessions between cultivated and wild species; thus constituting an invaluable source of variability for the development of breeding program underway.

In the '90s, the sunflower crop was displaced towards areas with lower quality and agroecological aptitude. This caused that the yields have not experienced significant increases in the last five years, despite the technological changes incorporated (FAS USDA 2021). These marginal areas are characterized by a marked water deficit, due to the reduction in the frequency of annual rainfall. These changes in the seasonal distribution cause a discrepancy between crop cycles and water availability in the soil. Consequently, the water stress produced during this period causes significant yield losses, also affecting the content and chemical quality of the oil in the seed (D. Álvarez personal communication). Therefore, the increase in the drought tolerance in sunflower hybrids is our goal and for this, it is interesting to explore the genetic resources in order to identify genomic regions associated with this trait. In this way, since 2005 different studies were done with accessions from the AGB-IM, to obtain a better knowledge about drought tolerance in this crop (Andrade et al. 2014; Moreno et al. 2014; Escalante et al. 2014; Grandón 2018; Grandón et al. 2018a, b). In this sense, the aim of this study was to select the best combination of contrasting parents to develop mapping populations for drought tolerance, based on phenotyping in the greenhouse conditions at vegetative stage and genotyping with SSR markers.

\section{Materials and methods}

Plant materials, growth conditions and experimental design

Seven inbred lines (ILs) belong to an association-mapping panel (AMP) established by Fusari et al. (2012) (Table 1), were included in this study for drought tolerance phenotyping and molecular assay. Six of them were previously evaluated for drought tolerance in the field, under well-watered (WW) and water-deficit (WD) conditions during 20032004 and 2004-2005 seasons at INTA Manfredi, province of Córdoba, Argentina (31 ${ }^{\circ} 49^{\prime} 12^{\prime \prime} \mathrm{S}, 63^{\circ} 46^{\prime} 00^{\prime \prime} \mathrm{W}$ ) (Andrade et al. 2009). Inbred lines were classified as sensitive and drought-tolerant based on the seed yield ha ${ }^{-1}$, oil yield $\mathrm{ha}^{-1}$ and the relative germination percentage in manitol (200 and $\left.400 \mathrm{mM}\right)$ in a lab test. Pereyra-Irujo et al. (2007) classified HA64 as drought-tolerant in greenhouse experiment for evaluate the response of leaf growth to water deficit.

Table 1 Description of sunflower inbred lines evaluated in this study

\begin{tabular}{lllll}
\hline $\begin{array}{l}\text { Inbred } \\
\text { lines }\end{array}$ & Pedigree & Origen & $\begin{array}{l}\text { Mantainer/ } \\
\text { Restorer }\end{array}$ & Field assay (2003-2005) \\
\hline B59 & derived B85-9-7 & Argentina & Mantainer & drought-sensitive
\end{tabular}




$\begin{array}{lllll}\text { R419 } & \text { HA89/T-//CF9 } & \text { Argentina } & \text { Restorer } & \text { drought-sensitive } \\ \text { HA89 } & \text { "Vniimk 8931" } & \text { USA } & \text { Mantainer } & \text { intermediate } \\ \text { R423 } & \text { M734/PNMR651 } & \text { Argentina } & \text { Restorer } & \text { intermediate } \\ \text { HAR4 } & \text { derived SAENZ PEÑA 74-1-2 } & \text { Argentina } & \text { Mantainer } & \text { drought-tolerant } \\ \text { R432 } & \text { PION6440/91T608//R049 } & \text { Argentina } & \text { Restorer } & \text { drought-tolerant } \\ \text { HA64 } & \text { derived VNIIMK 1646 } & \text { USA } & \text { Mantainer } & \text { drought-tolerant }\end{array}$

94

Three seeds of each ILs genotype were sown in PVC pipe pots filled with $4000 \mathrm{~g}$ of soil (typic Haplustoll, Serie Oncativo) and it were kept in the greenhouse conditions from September to October 2018 at INTA Manfredi. Those were arranged following a randomized complete block design with six replicas under two water treatments: wellwatered (WW) and water-deficit (WD). Water deficit (70\% of WW condition) was induced at eight-leaf stage for a period of 16 days. Gravimetric moisture contents at field capacity and permanent wilting point were measured initially. Based on these water constants the target weight was determined for each water condition, which were maintained with the irrigation applied daily. Seedlings were thinned to one plant per pot and were grown without water limitations until eight-leaf stage initiation in each IL. At this moment, soil water content was gradually decreased using the method described in Pereyra-Irujo et al. (2007). Then, the pots were covered with polyethylene to prevent evaporation from the ground. They were weighed and watered manually according to the water content in each treatment conditions. The growth conditions were $16 \mathrm{~h}$ photoperiod, $32 / 14{ }^{\circ} \mathrm{C}$ day/night, 39/79 \% RH day/night and 3.24/1.43 kPa VPD day/night. Air temperature $\left(\mathrm{T}^{\circ} \mathrm{C}\right)$ and relative humidity $(\mathrm{RH})$ were automatically recorded every hour with a data logger (Lascar, China). The value of vapor pressure deficits (VPD) was calculated daily as the difference between the saturated vapor pressure $\left(e_{a}\right)$ and the actual vapor pressure $\left(e_{d}\right)$, using daily maximum and minimum temperature $(T$ max and $T$ min, respectively) and daily RHmax and RHmin, following the procedure described by Abbate et al. (2004):

$$
\begin{gathered}
V P D=e_{a}-e_{d} \\
e_{a}=e_{a(\text { Tmax })} \theta+e_{a(\text { Tmin })}(1-\theta) \\
e_{d}=\left[e_{d(\text { Tmax })}+e_{d(T \min )}\right] / 2 \\
e_{d(\text { Tmax })}=e_{a(\text { Tmax })} \mathrm{RH}_{\min } / 100 \\
e_{d(\text { Tmin })}=e_{a(\text { Tmin })} \mathrm{RH}_{\text {max }} / 100 \\
e_{a(T i)}=0.611 \exp \left(\frac{17.27 T i}{T i+237.3}\right)
\end{gathered}
$$

where $\theta$ is a weighing parameter: 0.72 for $T \max$ and 0.28 for $T \min ; T i$ is $T \max$ or $T \min ; T$ max: maximum temperature; $T$ min: minimum temperature; RHmax: maximum relative humidity; RHmin: minimum relative humidity.

\section{Trait Measurements}

Each seven days, the leaf area (LA), plant height and stem diameter were recorded as well as at the beginning and the end of the water stress period. The LA was recorded with scale as the width of each leaf and was estimated using the allometric relationships shown in Vega et al. (2001) and Druetta (2016). Gain of leaf area (GLA) was determined like differences between total leaf area per plant (TLAp) at the end and the beginning of the water stress period. Both dry weight (DW) and fresh weight (FW) were estimated at the beginning of the water stress period from the volume of the plant (plant height *stem diameter) and the TLAp, using the allometric relationships shown in Vega et al. (2001) and Druetta (2016). At the end of the experiment the shoots and roots were harvested and weighted and then were oven-dried at $105^{\circ} \mathrm{C}$ for $24 \mathrm{~h}$, to determine total DW. Water transpired (WT) per plant was estimated every day from the difference in the pot weight. Total water use (TWU) per plant was calculated at the end of the experiment by accumulating daily WT during the effective stress period. Net assimilation rate (NAR) was determined from the LA and total DW per plant (shoots + roots) with the following formula: 


$$
\mathrm{NAR}=\frac{\left(\mathrm{W}_{2}-\mathrm{W}_{1}\right)\left(\log _{\mathrm{e}} \mathrm{L}_{2}-\log _{\mathrm{e}} \mathrm{L}_{2}\right)}{\left(\mathrm{L}_{2}-\mathrm{L}_{1}\right)\left(\mathrm{t}_{2}-\mathrm{t}_{1}\right)}
$$

where $\mathrm{W}_{1}$ and $\mathrm{W}_{2}$ are total dry weight and $\mathrm{L}_{1}$ and $\mathrm{L}_{2}$ total leaf area at times $\mathrm{t}_{1}$ and $\mathrm{t}_{2}$, respectively.

Water use efficiency (WUE) (on a whole plant basis) was determined at the end of the experiments as the ratio of dry weight gain ( $D W G=W_{2}-W_{1}$ ) to TWU during the effective water stress period. For daily transpiration rate (TR) response to vapor pressure deficit (VPD), slope and breakpoint were estimated from non-linear regression. The TR daily was calculated as the ratio of WT to LA per plant and VPD was estimated as detailed above.

Molecular assay

The genomic DNA from each IL was isolated from $10 \mathrm{mg}$ of lyophilized material according to a modified CTAB method (Doyle and Doyle 1987), and quantified by spectrophotometry (NanoDrop 8000, Thermo Fisher Scientific, USA). A set of 127 SSR markers available on public basis (https://www.ncbi.nlm.nih.gov/nuccore) was selected and screened for polymorphisms among seven ILs. Genotyping was performed by multiplex PCR assays (two or three primers for reaction) designed with the Multiplex Manager software (Holleley and Geerts 2009); using a kit multiplex PCR (QIAGEN, Hilden, Germany). Amplifications were conducted in a GeneAmp PCR System 9700 thermocycler (Applied Biosystems, USA) following an initial denaturation step at $95{ }^{\circ} \mathrm{C}$ for $15 \mathrm{~min}$, followed by 30 cycle of $94{ }^{\circ} \mathrm{C}$ for $30 \mathrm{~s}, 60{ }^{\circ} \mathrm{C}$ for $90 \mathrm{~s}$ and $72{ }^{\circ} \mathrm{C}$ for $60 \mathrm{~s}$, with a final extension of $60{ }^{\circ} \mathrm{C}$ for $20 \mathrm{~min}$. Separation of PCR products was performed in $6 \%$ denaturing polyacrylamide gel electrophoresis and visualized by silver nitrate stained according to Creste et al. (2001) and the fragment size was estimated using a DNA ladder 10 bp (Invitrogen, USA).

\section{Data analysis}

Principal components analysis (PCA), non-linear regression, LSD Fisher test and Pearson's correlation coefficients were carried out using InfoStat (Di Rienzo et al. 2011). Mixed generalized linear models was performed using SAS University Edition 3.6 (SAS 2016). Genotypes, treatments and interactions were considered as a fixed factor and replicate nested in each table was considered as a random factor. The polymorphism was determined between the possible combinations of contrasting parental for drought tolerance. Cluster Analysis was performed from the Nei's genetic distance (Nei 1972) and UPGMA algorithm. Molecular analysis was conducted with Infogen software (Balzarini and Di Rienzo 2011).

\section{Results}

Significant differences were observed between genotypes and water treatments for all traits. While the interaction was also significant for NAR ( $\mathrm{p}=0.0022)$, WUE $(\mathrm{p}=0.0264)$ and the breakpoint to the VPD response $(\mathrm{p}=0.0021)$.

The genotype B59 presented higher average value for GLA $\left(502.72 \pm 109.16 \mathrm{~cm}^{2}\right)$, while R419 showed lower average value $\left(162.43 \pm 100.39 \mathrm{~cm}^{2}\right)$ for this trait. Significant differences between water treatments were also observed for plants under WD condition with an $18 \%$ average reduction $(\mathrm{p}=0.0004)$. However, HA64 showed a significant reduction $(27 \%)$ between both conditions $(\mathrm{p}=0.0080)$ (Figure 1A). Regarding the total water use (TWU), significant differences was observed between genotypes $(\mathrm{p}<0.0001)$. For this trait, B59 presented highest average value $(2524.00$ $\pm 554.20 \mathrm{gH}_{2} \mathrm{O}$. day $\left.^{-1}\right)$ whereas $\mathrm{R} 419$ showed the lowest one $\left(1685.75 \pm 399.72 \mathrm{gH}_{2} \mathrm{O}\right.$.day ${ }^{-1}$ ) (Figure 1B). Significant differences were also observed between water treatments with a $23 \%$ average reduction for plants under WD. This situation was evident for HAR4 (reduction of 32\%), B59 and R419 (both with a reduction of 29\%) (p<0.05). 


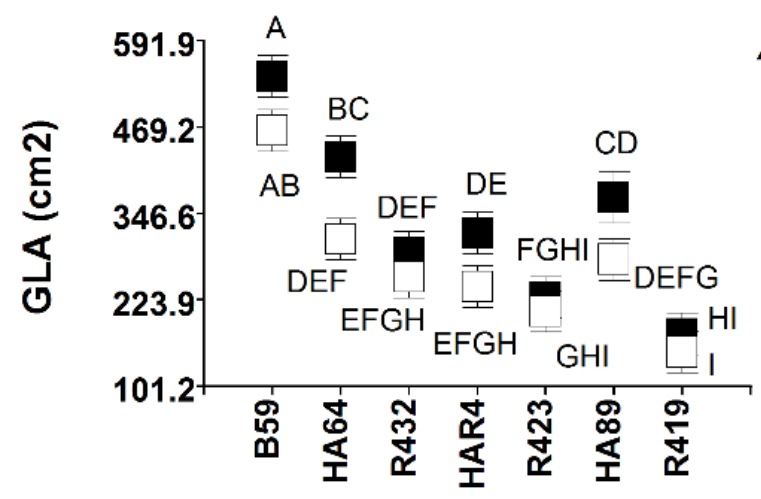

Inbred lines

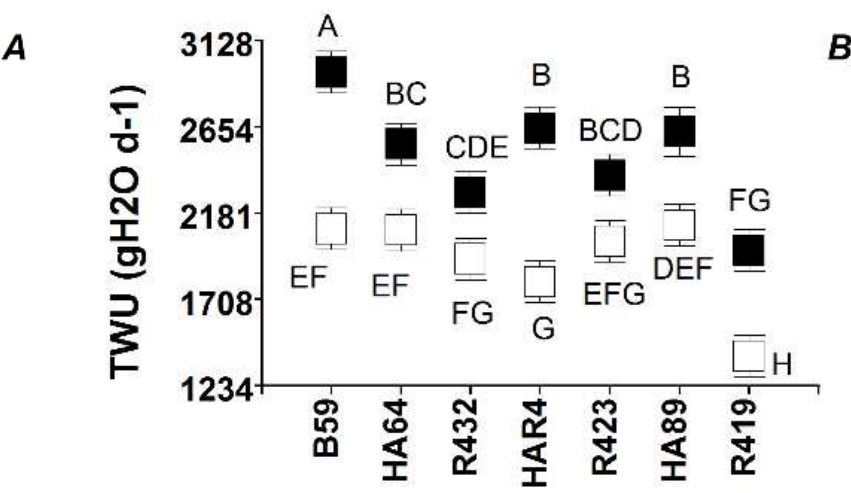

Inbred lines

Fig. 1 a GLA and b TWU traits for seven inbred lines evaluated under well-watered (WW) (full spot) and waterdeficit (WD) (empty spot) conditions. Data are means \pm SE of six replicates. Values with the same letter are not significantly different $(\mathrm{p} \geq 0.05)$

NAR trait showed an increase in the WD condition (Figure 2A). Thus, both HA64 (p<0.0001) and HAR4 $(\mathrm{p}=0.0006)$ presented a significant difference between two water treatments, which increased under WD of $35 \%$ and $23 \%$, respectively. Moreover, significant differences were observed between water treatments with an increase in efficiency under water-stress of $32 \%$ ( $\mathrm{p}<0.0001$ ) (Figure 2B). Besides, genotypic variability was observed for WUE trait under vegetative stage, being HA64 and HAR4 those that presented greater significant differences ( $<<0.05)$ between WW and WD conditions (55 and 39\%, respectively). In addition, the other genotypes showed between 19 and $35 \%$ of increased $(\mathrm{p}<0.05)$ between both water conditions.
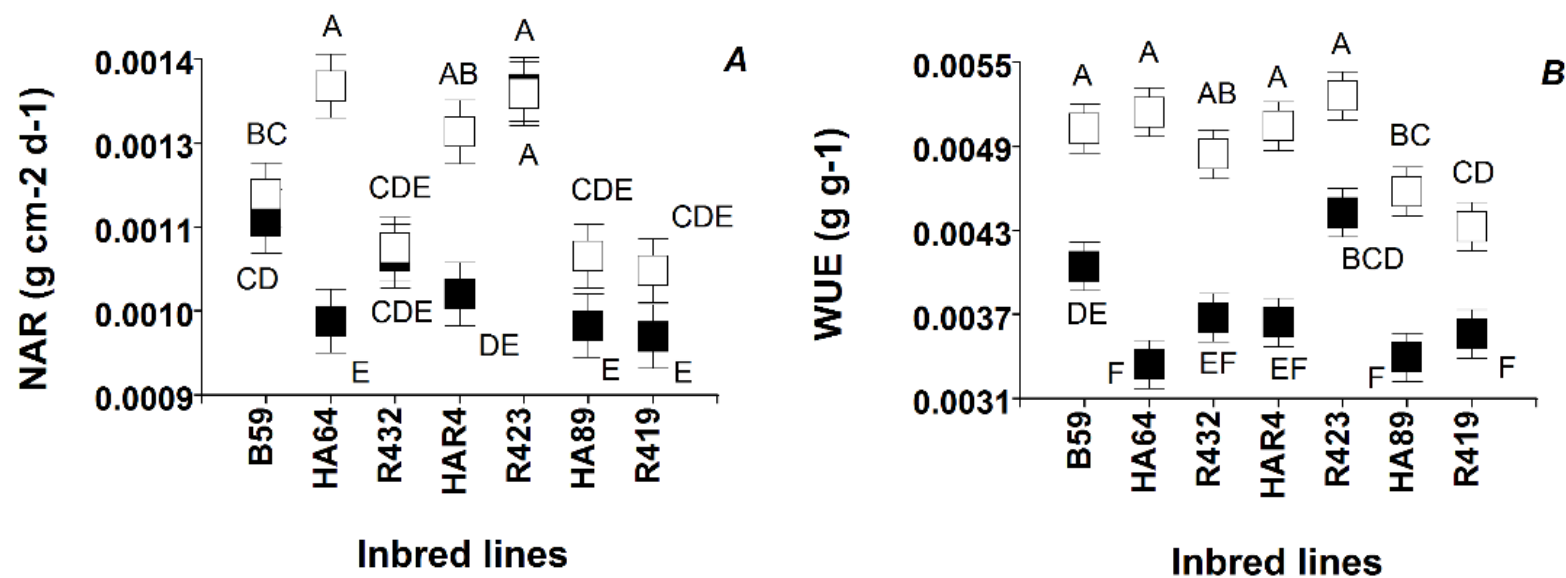

Fig. 2 a NAR and b WUE traits for seven inbred lines evaluated under well-watered (WW) (full spot) and waterdeficit (WD) (empty spot) conditions. Data are means \pm SE of six replicates. Values with the same letter are not significantly different $(\mathrm{p} \geq 0.05)$

Significant differences were observed for genotypes $(\mathrm{p}<0.0001)$ and water treatments $(\mathrm{p}=0.0026)$ (Figure $3 \mathrm{~A})$ in the relation between daily transpiration rate (TR) and vapor pressure deficit (VPD). HA64 and R432 presented higher slope, whereas R419 and HA89 showed a lower slope in VPD response (Figure 3A and 4A). Although there was an average reduction of $6 \%$ between WW and WD conditions (Figure 4B), only R419 ( $\mathrm{p}=0.0480)$ and $\mathrm{R} 423(\mathrm{p}=0.0111$ ) showed significant differences between both water conditions (Figure 3A). In addition, significant differences were observed for the breakpoint in VPD response both genotypes and water treatments $(\mathrm{p}=<0.0001)$, as well as significant 
interaction ( $\mathrm{p}=0.0021$ ) (Figure 3B). Thus, HA64 and R432 showed lower breakpoint and reached a limitedtranspiration rate $\left(\mathrm{TR}_{\mathrm{lim}}\right)$ at a lower VPD value, whereas $\mathrm{R} 419$ and HA89 showed, higher breakpoint both water contents (Figure 3B and 4A). Nevertheless, only HA64 ( $\mathrm{p}=0.0493), \mathrm{R} 432(\mathrm{p}=0.0041)$ and HA89 ( $<0.0001)$ showed significant differences between water treatments. Being the latter, which showed the biggest difference between both water conditions (an average reduction of 13\%). Instead, HAR4 did not show significant differences between water treatments $(\mathrm{p}=0.9067)$, hence under WD maintained its $\mathrm{TR}_{\lim }$ (Figure 3B). In addition, an average reduction of $5 \%$ $\mathrm{WD}$ treatments with respect to $\mathrm{WW}$ condition was observed, thus decreasing the $\mathrm{TR}_{\text {lim }}$ reached by each genotypes (Figure 4B).

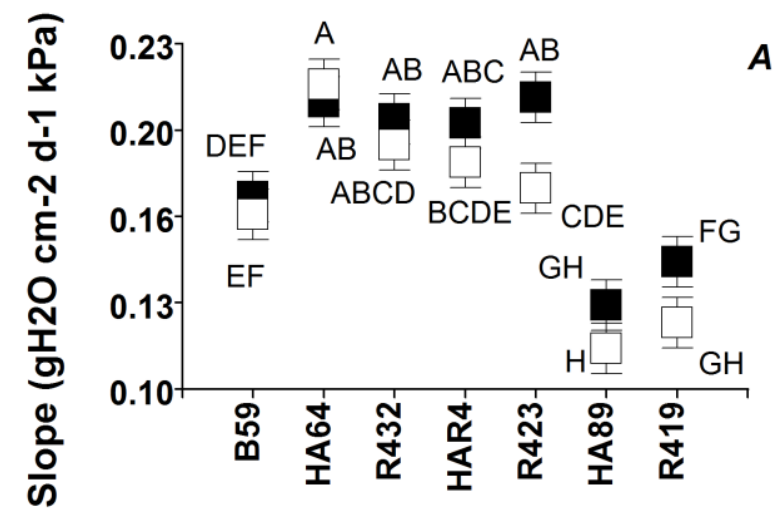

Inbred lines

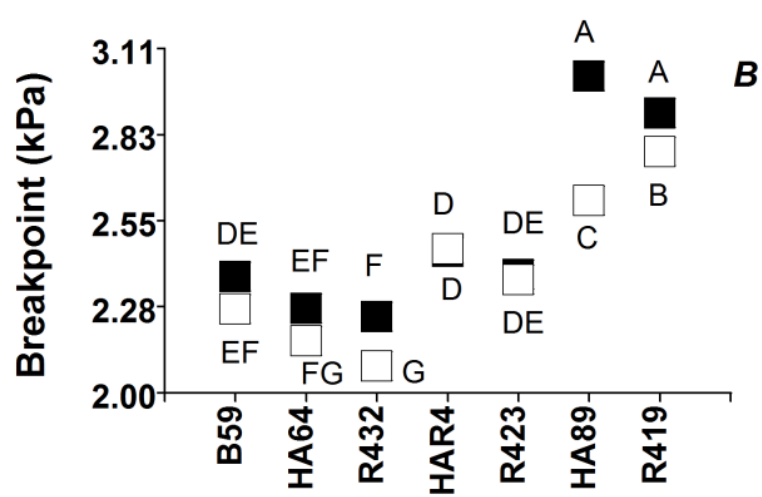

Inbred lines

Fig. 3 a Slope and $\mathbf{b}$ Breakpoint in the VPD response for seven inbred lines evaluated under well-watered (WW) (full spot) and water-deficit (WD) (empty spot) conditions. Data are means \pm SE of six replicates. Values with the same letter are not significantly different $(\mathrm{p} \geq 0.05)$
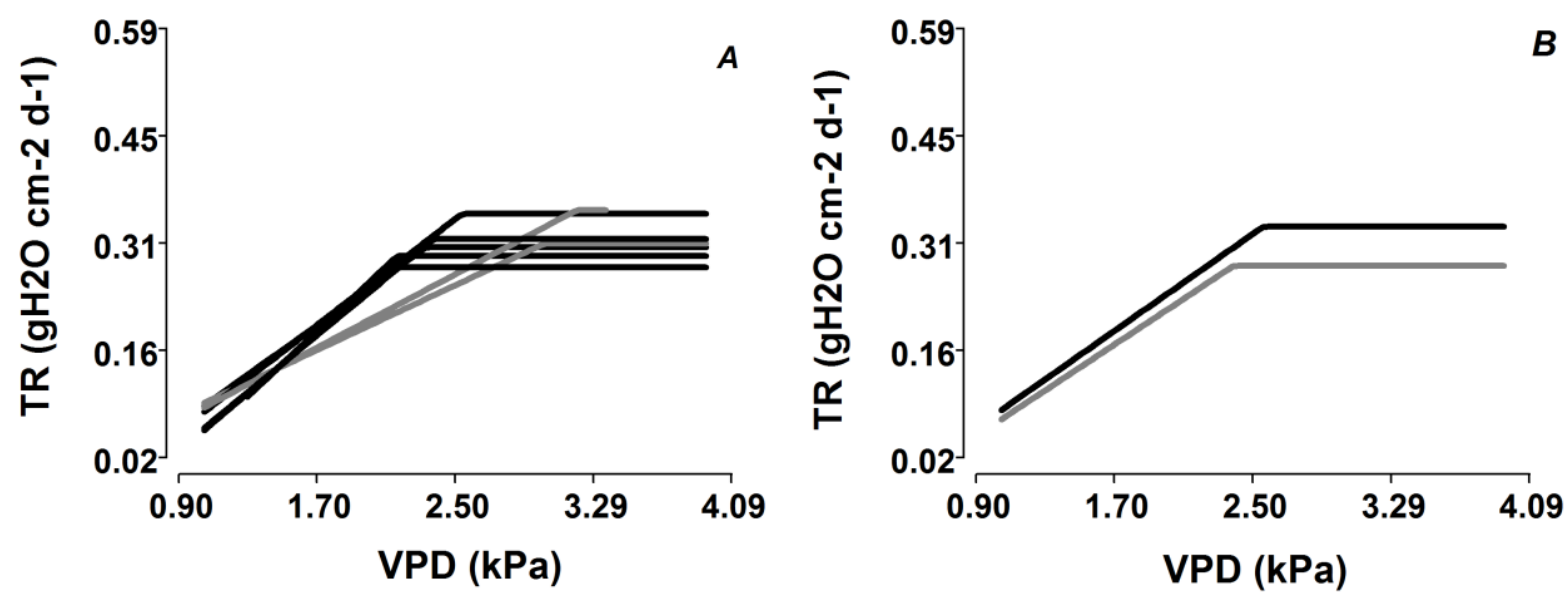

Fig. 4 Transpiration rate (TR) response to increasing vapor pressure deficit (VPD), a for seven inbred lines evaluated: B59, HA64, R423, R432 and HAR4 (black line); R419 and HA89 (grey line). b for well-watered (WW) (black line) and water-deficit (WD) (grey line) conditions

The Principal Component Analysis (PCA) explains the $80 \%$ of the total variability (Figure 5). PC1 (43.8\%) discriminated HA89 and R419 from the other genotypes due to a lower slope and higher breakpoint, both for WW and for WD treatments. Likewise, PC2 (35.9\%) separated all genotypes by water treatment based on WUE and TWU values. 


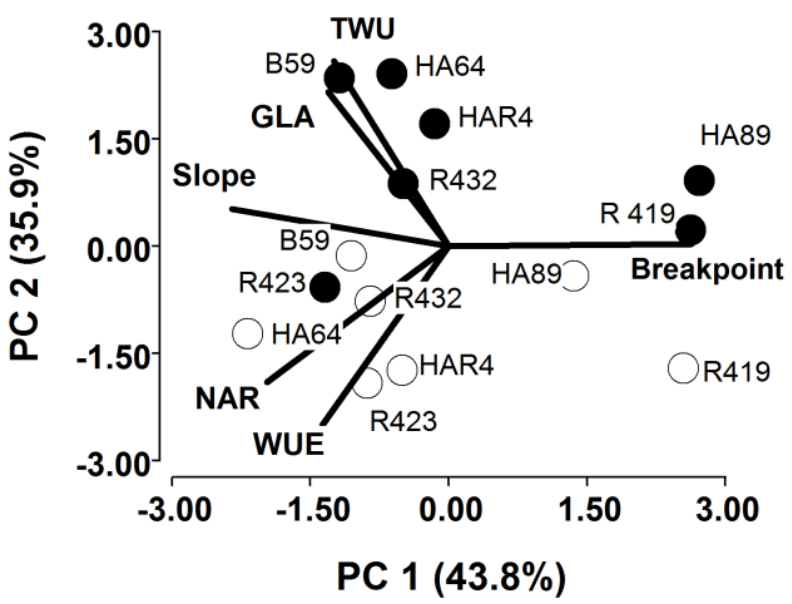

Fig. 5 PCA based on six traits evaluated in seven inbred lines under well-watered (WW) (full spot) and waterdeficit (WD) (empty spot) conditions. GLA: Gain of Leaf Area, TWU: Total Water Use, NAR: Net Assimilation Rate, WUE: Water Use Efficiency

The correlation between traits was analyzed by Pearson correlation coefficients (Table 2). A higher significant positive correlation was found both GLA and TWU $(r=0.60, p<0.0001)$ and NAR and WUE $(r=0.77, p<0.0001)$. Whereas, a higher significant negative correlation was found between slope and breakpoint in the VPD response $(\mathrm{r}=$ $-0.73, \mathrm{p}<0.0001)$.

Table 2 Pearson correlation coefficients (r) between six traits evaluated in seven inbred lines. Lower diagonal: rvalues. Upper diagonal: p-value.

\begin{tabular}{lllllll}
\hline Traits & WUE & Slope & Breakpoint & TWU & GLA & NAR \\
\hline WUE & 1 & 0.957 & 0.003 & 0.004 & 0.975 & 0.000 \\
Slope & -0.01 & 1 & 0.000 & 0.017 & 0.172 & 0.003 \\
Breakpoint & -0.32 & -0.73 & 1 & 0.029 & 0.022 & 0.001 \\
TWU & -0.32 & 0.26 & -0.24 & 1 & 0.000 & 0.292 \\
GLA & 0.00 & 0.15 & -0.25 & 0.60 & 1 & 0.786 \\
NAR & 0.77 & 0.32 & -0.36 & -0.12 & 0.03 & 1
\end{tabular}

WUE: Water Use Efficiency; TWU: Total Water Use; GLA: Gain of Leaf Area; NAR: Net Assimilation Rate.

According to traits evaluated, ILs were classified as high (HA64 and HAR4), intermediate (B59, R423 and R432) and low transpiration efficiency (TE) (HA89 and R419). Additionally, HAR4 (high TE) and R419 (low TE) show the same behavior for drought-stress both in the greenhouse and in the field assay (Andrade et al. 2009); maintaining the same TE of each genotype both in the vegetative and the reproductive stages.

These seven ILs were genotyped with 127 SSR markers of which amplified 91 loci that allowed identifying 262 alleles, as well as a high level of polymorphism between the possible combinations of contrasting parents (Table 3). In addition, a neighbor-joining tree (Figure 6) was constructed based on the Nei Standard genetic distances (Nei 1972) calculated between pairs of ILs. At a distance of 1.05, two groups can be identified; one (group 1) composed of maintainer lines (HAR4 and B59) and the other (group 2) was dominated by the presence of restorer lines and separated into two subgroups. One of them contains R423, HA89 and R419 (subgroup 1) and the other subgroup consisting of R432 and HA64. However, based on the phenotyping, there were four possible combinations of contrasting parents, but only R419xHA64 and HA89xHAR4 had a greater genetic distance, besides a high polymorphism level between them (Table 3 ). 
Table 3 Level of polymorphism between possible combinations of contrasting parents for 91 SSR markers analyzed

\begin{tabular}{lllrr}
\hline \multicolumn{2}{l}{ Parental combination } & $\begin{array}{l}\text { Behavior against } \\
\text { water-deficit in the } \\
\text { greenhouse }\end{array}$ & $\begin{array}{l}\text { Level of } \\
\text { polymorphism }\end{array}$ & $\begin{array}{l}\text { Nei } \\
\text { Standard } \\
\text { distance }\end{array}$ \\
\hline Remale & Male & low TE x high TE & $59 \%$ & 1.08 \\
R419 & HA64 & low TE x high TE & $59 \%$ & 1.01 \\
HA89 & HAR4 & low TE x high TE & $43 \%$ & 0.70 \\
HA89 & HA64 & low TE x high TE & $60 \%$ & 1.08 \\
\hline
\end{tabular}

TE: transpiration efficiency.

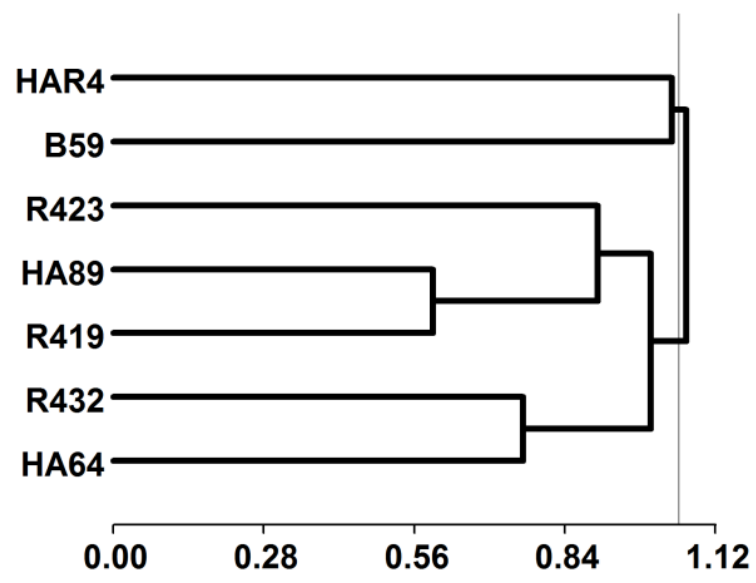

Fig. 6 Neighbor-Joining tree constructed based on the Nei Standard genetic distances and UPGMA algorithm for seven inbred lines. Cofenetic correlation coefficient: 0.71

\section{Discussion}

Based on these results, four combinations of contrasting parents were achieved, but only R419xHA64 and HA89xHAR4 showed the highest phenotypic contrast. Besides, a greater genetic distance (1.08) and a high polymorphism level between them (about 60\%) (Table 3). That is why these are the most suitable combinations of contrasting parents to develop mapping populations for drought tolerance in sunflower.

Phenotyping assay allow finding a differential response to water stress, among those contrasting genotypes potential to be used as parents to build segregating mapping populations. Thus, the selection of highly contrasting genotypes increase the probability of finding genomic regions or allelic variants associated with the trait. Consequently, the phenotyping must be accurate and show an experimental design that allows finding significant differences between parental evaluated. In addition, a greater genetic distance and a high level of marker polymorphism between genotypes also increase the probability of finding QTLs associated with the trait. In this study, phenotyping for drought tolerance was made in a greenhouse during vegetative stage for 16 days. Based on these results, a wide genotypic variation of response was observed for traits and water stress level evaluated in seven inbred lines. Phenotyping in the greenhouse allows have greater control of the atmospheric demand generated and management issues such as water-stress level applied. This also allows determining the individual plant behavior at an early development stage and in short testing times (Casadebaig et al. 2008; Velázquez et al. 2017).

Although leaf expansion is the first morpho-physiological process affected by water-deficit due to the reduction in cell division and cell expansion (Pereyra-Irujo et al. 2008), the leaf conductance it would also be affected by stomatal closure. This mechanism is one of the main causes of reduction of transpiration rate under water-deficit; because of a reduction in leaf water potential causes a decrease in leaf conductance avoiding excessive water loss (Hsiao 1973). Likewise, Nardini and Salleo (2005) reported that stomatal opening was reduced between 28 and 50\% when water- 
stress increased from moderate to severe, respectively. Therefore, in our experiments all genotypes showed lower GLA (average decreased of 18\%) and TWU (average decreased of 23\%) under WD conditions. For the GLA trait, HA64 genotype was the unique IL, which showed significant differences between both water conditions (a decrease of $27 \%$ ) and consequently, a reduction of $18 \%$ of TWU. Moreover, HAR4, B59 and R419 also showed significant differences $(\mathrm{p}<0,05)$ between WW and WD conditions for the last because of the lower GLA. In this sense, the reduction on transpiration rate under water-stress is a consequence of the reduction of GLA and the decline of stomatal opening. Similarly, Pereyra-Irujo et al. (2008) found variation for leaf expansion among genotypes analyzed, suggesting that those with the greatest reduction in leaf expansion rate had a high osmotic adjustment (OA). In agreement with this, Chimenti and Hall (1994) observed that sunflower genotypes with high OA showed less leaf expansion. Thus, they conclude that there is a negative association between these traits, probably because of reduction in leaf expansion is the most important mechanisms to avoid water loss.

The net assimilation rate (NAR) is an index that measures the photosynthetic efficiency and the net gain of assimilated per unit leaf area and unit of time (Morales-Morales et al. 2015). This index reaches maximum values in the vegetative stage and then decreases due to the increase of non-photosynthetic dry matter. In this study, NAR trait showed an increase in the WD treatment with respect to control. Thus, HA64 and HAR4 were the unique genotypes that showed a significant increase under WD (35\% and 23\%, respectively). This could be explained according to what was reported by Velázquez et al. (2017), who observed an increase in the number of stomata per unit leaf area under water-stress (75\% more in HA64). Similarly, Carrera et al. (2021) found in soybean $28 \%$ more stomata under waterstress compared to the non-stressed control. However, they did not observe that water-deficit significantly affected the photosynthetic efficiency of photosystem II. Therefore, this would keep photosynthesis active without greatly modifying the accumulation of biomass.

Water use efficiency (WUE) is defined as dry matter produced per unit of water transpired and expresses the efficiency with which a crop fixes $\mathrm{CO}_{2}$ in relation to the water it loses (Dardanelli et al. 2003). Prieto et al. (2007, 2011) reported that WUE is a constitutive trait that shows intraspecific variation and increases in response to waterdeficit during the vegetative stage in soybeans. For this reason, this trait has been considered as a selection criterion due to its association with drought tolerance in other crops such as wheat, barley and soybean (Condon et al. 2004; Prieto et al. 2007). In this study, the increase in WUE under water-deficit (32\% with respect to control) would indicate that stressed plants were more efficient and conservative with water in the tissues, producing more dry matter per gram of water transpired. Similarly, Prieto et al. (2011) observed this behavior in soybean during the vegetative stage. In addition, this difference between treatments was also observed by Velázquez et al. (2017) who detected between 15 and 30\% increase in WUE under water-deficit in sunflower during the vegetative stage.

The transpiration rate (TR) is defined as the water transpired per unit leaf area per unit of time and depends on the concentration gradient of water vapor (estimated from the Vapor Pressure Deficit or VPD) between the subestomatic cavity and the air surrounding the leaf. As the VPD increases, the TR also increases; however, this increase is not unlimited since the TR reaches a limit $\left(\mathrm{TR}_{\lim }\right)$ above a threshold value of VPD or breakpoint (Turner et al. 1984). For establish the relationship between daily TR and VPD response under two water conditions, the slope and the breakpoint were determined. The evidence is that under WD there was a decrease in the slope and breakpoint (6\% and $5 \%$, respectively), decreasing the $\mathrm{TR}_{\lim }$ reached by each line. Thus, ILs with higher slope showed lower breakpoint (HA64 and R432) and those with lower slope showed a higher breakpoint (R419 and HA89) (Figure 3). Therefore, HA64 and R432 reached the TR $\mathrm{Iim}_{\lim }$ at a lower VPD, reduced the stomatal conductance and consequently the water loss. Instead, R419 and HA89 reached the $\mathrm{TR}_{\lim }$ at a higher VPD, probably due to a lower stomatal sensitivity to water deficit (Turner et al. 1985). Although the photosynthetic rate is proportional to the TR (Tanner et al. 1983), it could be higher at times of the day where the VPD is less than $2.46 \mathrm{kPa}$. The practical significance of the TR-VPD response is that above the break point (specific for each genotype) there is a limitation in the TR due to an increase in stomatal sensitivity, resulting in the conservation of water in the tissues. Thus, the results of this work contribute to demonstrate the existence of significant differences between genotypes for this relationship under conditions of water limitation during the vegetative stage in sunflower. According to Sinclair et al. (2008), the breakpoint as a response to a limited hydraulic conductance $(K)$ in the leaf, that constrains the flow of water from the xylem into the guard cells under highevaporative conditions, i.e. high VPD. This would lead to a loss of turgor in the guard cells and a reduction of stomatal conductance (Turner et al. 1985; Nardini and Salleo 2005). In this sense, Sadok and Sinclair (2010) and Nardini et al. (2005), determined that the reduction in hydraulic conductance would be associated with the decrease in the expression or activity of aquaporins sensitive to silver nitrate $\left(\mathrm{AgNO}_{3}\right)$ in soybeans and to mercury chloride $\left(\mathrm{HgCl}_{2}\right)$ in sunflower, respectively. Therefore, these authors suggest that a reduction in the expression of these proteins would restrict the flow of water causing the TR to reach a limit and remain stable at a high VPD. The changes in aquaporins transcripts 
and their involvement in limited transpiration to VPD was also observed in different crops like soybean and maize (Devi et al. 2016; Devi and Reddy, 2020).

Concerning PCA analysis, PC1 discriminated HA89 and R419 from the other ILs due to a lower slope and higher breakpoint for both treatments; whereas PC2 separated all genotypes by treatment based on WUE and TWU values. In this regard, plants under WD condition showed lower water consumption and were more conservative with the water in the tissues. Thus, HA89 and R419 that showed lower WUE and NAR may be classified as low photosynthetic and transpiration efficiency (TE), whereas the other genotypes presented an intermediate or high TE. Nevertheless, a significant positive correlation was found between GLA and TWU ( $r=0.60, \mathrm{p}<0.0001)$. This association was also observed by Pereyra-Irujo et al. (2007), who determined that the water consumption rate depends largely on the leaf area of each genotype. Therefore, under WD there is a reduction in the volume of water transpired as a consequence of the decrease in the total leaf area (Golberg 2008). Instead, a significant negative correlation was found between slope and breakpoint in the VPD response $(\mathrm{r}=-0.73, \mathrm{p}<0.0001)$. This correlation was also reported by Gholipoor et al. (2010) in sorghum. Regarding, the negative correlation between WUE and TWU ( $\mathrm{r}=-0.32$ ) was also observed by Adiredjo et al. (2014a, b) and Velázquez et al. (2017) (Table 2), since a higher water loss would reduce the TE. Therefore, based on this results ILs were classified as high TE (HA64 and HAR4), intermediate TE (B59, R423 and R432) and low TE (HA89 and R419).

In order to establish the genetic relationship between ILs evaluated, a cluster analysis was performed. Thus, a neighbor-joining tree was constructed (Figure 6) and at a distance of 1.05, two well-defined groups can be identified. One of them (group 1) was composed of maintainer lines of Argentinian origin (HAR4 and B59) and the other (group 2 ) was dominated by the presence of restorer lines and separated into two subgroups at a distance of 0.95 . One of these contains R423, HA89 and R419 (subgroup 1) which is expected since R419 derives from HA89. While grouping with R423 was probably due to is a restorer line of Argentinian origin, just like R419. The second subgroup was conformed by R432 and HA64 because of they share 45\% of similarity among the SSR markers analyzed. Although in the records HA64 is from USA and R432 is from Argentinian germplasm, these could have some common origin, which would cause them to be located together in the neighbor-joining tree. These groups are coincident with that found by Filippi et al. (2015) in their cluster analysis for 42 SSR in 170 sunflower ILs from the INTA - AMP.

Based on phenotyping results, four possible combinations between contrasting parents were achieved (Table 3). However, only two (R419xHA64 and HA89xHAR4) showed a greater genetic distance (1.08) and a high level of polymorphic markers between them (about 60\%). In conclusion, these would be the best combinations to develop mapping populations for drought tolerance in sunflower. Currently, the $F_{3}$ populations were sowing in this 2021-2022 campaign. These will serve to identify new genomic regions or to validate SNPs variants associated with this trait, previously identified in the association mapping population to which they belong. Our results suggest that it is relevant a previously analysis with phenotypic and genotypic data to performs a correct selection of parental lines for the develop of mapping population for quantitative traits like as drought tolerance and this combined evaluation might be an important point that could be suggested to be applied in other breeding programs of the crop.

\section{Acknowledgments}

This research was supported by Instituto Nacional de Tecnología Agropecuaria (PNBIO-1131042 and INTA Posgraduate Funding Program). We are also grateful to Maximiliano Casalanguida, Gaspar Yachetta and Luis Mecchia for their support in the greenhouse experiments. We thanks to Ing. Daniel Álvarez (Sunflower breeder of INTA Manfredi) for make available the seeds of the evaluated inbred lines.

\section{References}

Abbate PE, Dardanelli JL, Cantarero MG, Maturano M, Melchiori RJM, Suero EE (2004) Climatic and water availability effects on water-use efficiency in wheat. Crop Sci. 44:474-483.

Adiredjo AL, Navaud O, Lamaze T, Grieu P (2014a) Leaf carbon isotope discrimination as an accurate indicator of water-use efficiency in sunflower genotypes subjected to five stable soil water contents. J Agro Crop Sci 200(6):416-424.

Adiredjo AL, Navaud O, Muños S, Langlade NB, Lamaze T, Grieu P (2014b) Genetic control of water use efficiency and leaf carbon isotope discrimination in sunflower (Helianthus annuus L.) subjected to two drought scenarios. PLoS ONE, 9(7):15 p. 
Andrade A, Vigliocco A, Alemano S (2009) Differential accumulation of abscisic acid and its catabolites in droughtsensitive and drought-tolerant sunflower seeds. Seed Science Research 19:201-211.

Andrade A, Vigliocco A, Escalante M, Alemano S (2014) Efecto del estrés hídrico e inhibidor de la síntesis de ácido jasmónico en plántulas de girasol (Helianthus annuus L.). En: XV Congreso Latinoamiericano. XXX Reunión Argentina de Fisiología Vegetal. 21 al 24 de septiembre de 2014. Mar del Plata, Buenos Aires (AR).

Badouin H, Gouzy J, Grassa CJ, Murat F, Staton E, Cottret L et al. (2017) The sunflower genome provides insights into oil metabolism, flowering and Asterid evolution. Nature 546:148-152.

Balzarini MG, Di Rienzo JA (2011) InfoGen versión 2011. Córdoba (AR): FCA, Universidad Nacional. Disponible en http://www.info-gen.com.ar

Carrera C, Solis S, Ferrucci M, Vega C, Galati B, Ergo V, Andrade F, Lascano R (2021) Leaf structure and ultrastructure changes induced by heat stress and drought during seed filling in field-grown soybean and their relationship with grain yield. An Acad Bras Cienc 93(4): e20191388 DOI 10.1590/0001-37652021XXXX.

Casadebaig P, Debaeke P, Lecoeur J (2008) Thresholds for leaf expansion and transpiration response to soil water deficit in a range of sunflower genotypes. Europ. J. Agronomy 28(4):646-654.

Chimenti CA, Hall AJ (1994) Responses to water stress of apoplastic fraction and bulk modulus of elasticity in sunflower (Helianthus annuus L.) genotypes of contrasting capacity for osmotic adjustment. Plant and Soil 166:101-107.

Condon AG, Richards RA, Rebetzke GJ, Farquar GD (2004) Breeding for high water-use efficiency. J. Exp. Bot 55:2447-2460.

Creste S, Tulmann Neto A, Figueira A (2001) Detection of single sequence repeat polymorphisms in denaturing polyacrylamide sequencing gels by silver staining. Plant Molecular Biology Reporter 19(4):299-306.

Dardanelli J, Collino D, Otegui ME, Sadras VO (2003) Bases funcionales para el manejo del agua en los sistemas de producción de los cultivos de grano. In: Pascale AJ (ed) Producción de granos: Bases funcionales para su manejo. Buenos Aires (AR): Universidad Nacional. Facultad de Agronomía. pp 375-440.

Devi MJ, Reddy VR (2020) Stomatal closure response to soil drying at different vapor pressure deficit conditions in maize. Plant Physiology and Biochemistry 154:714-722. https://doi.org/10.1016/j.plaphy.2020.07.023

Devi MJ, Sinclair TR, Taliercio E (2016) Silver and zinc inhibitors influence transpiration rate and aquaporin transcript abundance in intact soybean plants. Environmental and Experimental Botany 122:168-175. http://dx.doi.org/10.1016/j.envexpbot.2015.10.006

Di Rienzo JA, Casanoves F, Balzarini MG, González L, Tablada M, Robledo CW (2011) InfoStat versión 2011. Grupo InfoStat. Córdoba (AR): Universidad Nacional. Facultad de Ciencias Agropecuaria. Available in http://www.infostat.com.ar.

Doyle JJ, Doyle JL (1987) A rapid DNA isolation procedure for small quantities of fresh leaf tissue. Phytochem Bull 19:11-15.

Druetta AL (2016) Caracterización fenotípica de la respuesta al estrés hídrico en líneas endocriadas de girasol (Helianthus aпnииs L). (Tesis inédita de Ingeniería). Villa María, Córdoba (AR): Universidad Nacional. Instituto A.P. Ciencias Básicas y Aplicadas. 54 p.

Escalante M, Andrade A, Vigliocco A Alemano S (2014) Evaluación geno-fenotípica de líneas endocriadas de girasol (B71 y B59) contrastantes en la respuesta a estrés hídrico y de sus poblaciones segregantes. In: $6^{\circ}$ Congreso Argentino de Girasol. 27 de mayo de 2014. Buenos Aires (AR).

FAS USDA (2021) Foreign Agricultural Service. United States Department of Agriculture. Market and Trade Data. PSD Online. Graphical Query: Stats by Country. Available in https://apps.fas.usda.gov/psdonline/app/index.html\#/app/compositeViz. 
Filippi CV, Aguirre N, Rivas JG, Zubrzycki J, Puebla A, Cordes D, et al. (2015) Population structure and genetic diversity characterization of a sunflower association mapping population using SSR and SNP markers. BMC Plant Biology 15(1):52.

Fusari CM, Di Rienzo JA, Troglia C, Nishinakamasu V, Moreno MV, Maringolo C, et al. (2012) Association mapping in sunflower for Sclerotinia Head Rot resistance. BMC Plant Biology 12:93 13 p.

Gholipoor M, Prasad PVV, Mutava RN, Sinclair TR (2010) Genetic variability of transpiration response to vapor pressure deficit among sorghum genotypes. Field Crops Research 119(1):85-90.

Golberg AD (2008). Las plantas frente a la limitación hídrica. In: Golberg AD Kin AG (eds) El agua: de la molécula a la biósfera. Santa Rosa, La Pampa (AR): Ediciones INTA. pp 97-130.

González J (2016) Mejoramiento genético de girasol (Helianthus annuus) en INTA - EEA Pergamino, a partir de distintas fuentes de germoplasma. Revista de Tecnología Agropecuaria 10(31):49-52.

González J, Mancuso N, Álvarez D, Cordes D, Vázquez A (2015) Contribution of the Argentine germplasm to the improvement of sunflower. Helia $20 \mathrm{p}$.

Grandón NG (2018). Caracterización molecular de cinco poblaciones de mapeo $\mathrm{F}_{2}$ en girasol cultivado (Helianthus annuus var. macrocarpus (DC) Cockerell) segregantes para tolerancia a estrés hídrico mediante marcadores microsatélites (Tesis inédita de Maestría). Rosario, Santa Fe (AR): Universidad Nacional. Facultad de Ciencias Agrarias. 108p. Available in https://repositorio.inta.gob.ar/xmlui/handle/20.500.12123/4269.

Grandón NG, Moreno MV, Mecchia L, Martin EA (2018a) Selección de una población de mapeo para la tolerancia al estrés hídrico en girasol (Helianthus annus var. macrocarpus (DC) Cockerell). III Jornadas Regionales de Genética del Litoral. 28 y 29 de junio de 2018. INTA Rafaela, Santa Fe (AR). Available in http://repositorio.inta.gob.ar/xmlui/handle/20.500.12123/3956.

Grandón N, Martin E, Cicconi E, Díaz C, Mamaní E, Yachetta G, Casalanguida M, Mecchia L, Moreno MV (2018b) Drought tolerance phenotyping in sunflower inbreed lines (Helianthus annuus var. macrocarpus (DC) Cockerell). XXXII Reunión Argentina de Fisiología Vegetal y XVI Congreso Latinoamericano de Fisiología Vegetal. 11 al 15 de noviembre de 2018. Córdoba (AR). Available in http://repositorio.inta.gob.ar/xmlui/handle/20.500.12123/3934

Holleley CE, Geerts PG (2009) Multiplex Manager 1.0: A cross-platform computer program that plans and optimizes multiplex PCR. BioTechniques 46(7):511-517.

Hsiao TC (1973) Plant responses to water stress. Ann Rev Plant Physiol 24:519-570.

Morales-Morales EJ, Morales-Rosales EJ, Díaz-López E, Cruz-Luna AJ, Medina-Arias N, Guerrero-De La Cruz M (2015) Tasa de asimilación neta y rendimiento de girasol en función de urea y urea de liberación lenta. Agrociencia 49(2):163-176.

Moreno MV, Buffa E, Passetti J, Cordes D, Alvarez D, Di Rienzo J, et al. (2014) Fenotipificación de líneas endocriadas de girasol (Helianthus anпииs L.) en respuesta a estrés hídrico temprano con perspectivas para su empleo en mapeo de asociación. In: XV Congreso Latinoamericano de Fisiología Vegetal. XXX Reunión Argentina de Fisiología Vegetal. 21 al 24 de septiembre de 2014. Mar del Plata, Buenos Aires (AR).

Nardini A, Salleo S (2005). Water stress-induced modifications of leaf hydraulic architecture in sunflower: coordination with gas exchange. Journal of Experimental Botany 56(422):3093-3101.

Nardini A, Salleo S, Andri S (2005) Circadian regulation of leaf hydraulic conductance in sunflower (Helianthus апnииs L. cv Margot). Plant Cell and Environment 28(6):750-759.

Nei M (1972) Genetic distance between populations. Amer Nat 106:283-292.

Pereyra-Irujo GA, Velázquez L, Granier C, Aguirrezábal LAN (2007) A method for drought tolerance screening in sunflower. Plant Breeding 126(4):445-448. 
Pereyra-Irujo GA, Velázquez L, Lechner L, Aguirrezábal LAN (2008) Genetic variability for leaf growth rate and duration under water deficit in sunflower: Analysis of responses at cell, organ, and plant level. Journal of Experimental Botany 59(8):2221-2232.

Prieto Angueira S, Vega CRC, Chimenti CA (2007) Variabilidad intraespecífica en eficiencia del uso del agua en soja [Glycine $\max$ (L.) Merril]. In: Workshop Internacional Ecofisiología Vegetal Aplicada al Estudio de la Determinación del Rendimiento y la Calidad de los Cultivos de Granos. Primer Encuentro Red de Raíces de Ecofisiología SECyT. 6 y 7 de septiembre de 2007. Mar del Plata, Buenos Aires (AR): FA-UBA, INTA y FCAUNMdP. p 86-87.

Prieto Angueira S, Vega CRC, Chimenti CA (2011) Respuesta de la tasa transpiratoria a cambios en el déficit de presión de vapor en condiciones hídricas contrastantes en genotipos de soja de diferente eficiencia transpiratoria. In: Quinto Congreso de la Soja del Mercosur. Primer Foro de la Soja Asia-Mercosur. 14 al 16 de septiembre. Rosario, Santa Fe (AR): Bolsa de Comercio de Rosario.

Sadok W, Sinclair TR (2010) Transpiration response of "slow-wilting" and commercial soybean (Glycine max (L.) Merr.) genotypes to three aquaporin inhibitors. Journal of Experimental Botany 61(3):821-829.

SAS (2016). SAS University Edition 3.6. SAS Institute Inc.

Sinclair TR, Zwieniecki MA, Holbrook NM (2008) Low leaf hydraulic conductance associated with drought tolerance in soybean. Physiologia Plantarum 132:446-451.

Tanner CB, Sinclair TR (1983) Efficient water use in crop production: Research or Re-Search? In: Taylor HM et al. (eds) Limitations to Efficient Water Use in Crop Production. Madison, WI (USA): ASA, CSSA, and SSSA. pp 127.

Turner NC, Schulze ED, Gollan T (1984) The responses of stomata and leaf gas exchange to vapour pressure deficits and soil water content. I. Species comparisons at high soil water contents. Oecologia 63:338-342.

Turner NC, Schulze E-D, Gollan T (1985) The responses of stomata and leaf gas exchange to vapour pressure deficits and soil water content II. In the mesophytic herbaceous species Helianthus annuus. Oecologia 65:348-355.

USDA (2021) United States Department of Agriculture. Foreign Agricultural Service. Office of Global Analysis. Oilseeds: World Markets and Trades. Current Reports: May 2021. Available in https://www.fas.usda.gov/data/oilseeds-world-markets-and-trade.

Vásquez A (2002) Mejoramiento genético. In: Díaz-Zorita M, Duarte GA (eds) Manual práctico para el cultivo de girasol. Buenos Aires (AR): Asociación Argentina de Girasol (ASAGIR). Hemisferio Sur S. A. pp 63-76.

Vega CRC, Andrade FH, Sadras VO (2001) Reproductive partitioning and seed set efficiency in soybean, sunflower and maize. Field Crop Research 72:163-175.

Velázquez L, Alberdi I, Paz C, Aguirrezábal L, Pereyra-Irujo G (2017) Biomass allocation patterns are linked to genotypic differences in whole plant transpiration efficiency in sunflower. Frontiers in Plant Science 8(1976):12 p.

\section{Statements \& Declarations}

\section{Funding}

This research was supported by Instituto Nacional de Tecnología Agropecuaria (PNBIO-1131042 and INTA Posgraduate Funding Program).

\section{Competing Interests}

The authors have no relevant financial or non-financial interests to disclose.

\section{Author Contributions}

All authors contributed to the study conception and design. Material preparation, data collection and analysis were performed by Nancy Gabriela Grandón, Eugenia Alejandra Martin, Emanuel Mauro Cicconi, Carolina del Pilar Díaz, 
490 Eva María Celia Mamaní and María Valeria Moreno. The first draft of the manuscript was written by Nancy Gabriela 491 Grandón and all authors commented on previous versions of the manuscript. All authors read and approved the final 492 manuscript.

\section{Data Availability}

The datasets generated during and/or analysed during the current study are available from the corresponding author on reasonable request. 